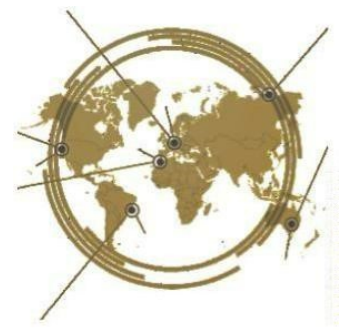

\title{
Preparing EFL pre-service teachers for curriculum 2013 through authentic materials and assessment integration
}

\begin{abstract}
Alan Jaelani ${ }^{*}$, Amalul Umam
English Language Education Department, Faculty of Teacher Training and Education, Universitas Ibn Khaldun Bogor, Indonesia

Changes in Curriculum lead to changes in teaching and learning processes as well as new ways to demonstrate best practices for increasing students' achievement. The Curriculum 2013 suggests teachers to use authentic materials and requires them to apply authentic assessments. It is quite challenging for English teachers because this condition creates problems especially for novice teachers. Therefore, they need to have prior knowledge and personal experience related to teaching practice and situation. In this study, authentic materials and authentic assessments were implemented in pre-serviceEnglish-teacher classroom at a university in Bogor, specifically in listening class, in order to familiarize them to the kind of materials and assessments. Action research was employed where documentation, observation, questionnaire, and interview were used to collect the data. The result shows that the integration of authentic materials and authentic assessment in EFL classroom helped the students in understanding the nature and the use of authentic materials and authentic assessment for their future needs of profession.
\end{abstract}

Keywords: Pre-service English Teacher; Curriculum 2013; Authentic Assessment; Authentic Materials

\section{INTRODUCTION}

A significant point in curriculum 2013 is creativity. Creativity can be defined as the competence of designing something interesting. Creativity in the curriculum refers to the activities of designing, implementing, and evaluating the teaching in an appropriate and dynamic way in accordance with the context, situation, or environment in which the teaching is taking place, so that the lesson will be conducive to achieving the goals that have been agreed upon beforehand (Nurkamto, 2016). Creativity in designing teaching materials needs to be taken into account. The materials fitted with the students' needs should be designed in interesting way and implemented based on the nature of the latest curriculum. Interesting teaching materials can be found in authentic materials.

Authentic materials are defined by Kiliçkaya (2004) as exposure to real language and use in its own community. Arianie (2017) argues when authentic materials are used with the purpose of students learning, they will have a sense that the real language for communication is being learnt, as opposed to classroom language itself. In contrast to the 
design of the text books, Lee(1995) states that authentic materials are intrinsically more active, interesting and stimulating. Richards (2001) suggests and mentions several reasons for using authentic materials in the classroom. These are: (1) they prepare learners for real life, (2) they meet learners' needs, (3) they affect learner motivation positively, (4) they encourage teachers to adopt effective teaching methods and (5) they present authentic information about culture. Arianie (2017) therefore assumes authentic materials help students grasp the use of language in the situations which are real.

The other significant point in Curriculum 2013 is the use of new method of assessment, namely authentic assessment. The regulation of the Minister of Education and Culture (Permendikbud No. 81A, 2013) about the implementation of Curriculum 2013 requires teachers to implement authentic assessments as the method of assessing the students' competence. The regulation of the National Minister of Education and Culture (Permendikbud No. 104 year 2014) on assessment system also expects teachers to assess students' skills using performance, project, and portfolio assessments (Rukmini \& Saputri (2017).

Authentic assessment is considered to be a new approach in assessment (Kinay, 2018). It is a form of assessment in which students are asked to perform real-world tasks that demonstrate meaningful application of essential knowledge and skills (Mueller, 2017). Umam \& Indah (2020) define authentic assessment as an actual measurement of students' attainment in their learning in which high level of cognitive ability, higher-order thinking and problem-solving skills are assessed in the form of tasks completion. Furthermore, Olfos \& Zulantay (2007) assume that authentic assessment is performance assessment, appropriate assessment, alternative assessment, or direct assessment, containing such techniques as written texts, portfolios, checklists, teacher observations, and group projects. The assessment stands for the application and utilization of knowledge as opposed to secluded skill assessments which contains the overall performance of meaningful but complicated tasks in challenging contexts (Montgomery, 2002).

Varela et al.(1997) classify authentic assessment into three types: performance assessment, portfolios, and students-self assessment. In line with the classification, the Curriculum 2013 mentions three types of authentic assessment: performance, portfolio, and project assessments. In reference to the regulation of the minister of education and culture number 81a year 2013, Rukmini \& Saputri (2017) assume that a performance assessment is an assessment which is conducted by observing student's activities in doing particular thing; a portfolio assessment is a purposeful collection of student's work that is intended to show the progress over time. Accordingly, Rukmini \& Saputri (2017) conclude that teachers are required to assess students' skills using performance, project, and portfolio assessments.

However, the implementation of authentic assessments is difficult and challenging for English teachers. A study conducted by Trisanti (2014) describes that teacher still had limited understanding about Curriculum2013; teacher also thought that the implementation of authentic assessment did not run effectively because of the complex procedure and the class condition. In addition, Rukmini \& Saputri (2017) assume that teachers' knowledge and their experience influences the implementation of the assessment. The teacher who has lack of knowledge of the nature and types of authentic assessments implements it improperly. The challenges are confirmed by Umam \& Indah (2020) assuming that "the goal of the curriculum can be achieved by giving attention to the content of the learning processes, teaching approach and assessment method."

In relation to the above findings and issues, the implementation of authentic materials and assessments certainly becomes more challenging for novice teachers as well. They need to have relevant prior knowledge and experience related to teaching practice and situation. In this regard, pre-service teachers need to be introduced and equipped with the knowledge of authentic and authentic assessment. Their exposure to the materials and assessment will result in their beliefs and competence in using the approach in the future professional as a real teacher.

In this study, therefore, authentic materials and authentic assessments were integrated in the pre-service class. The integration of knowledge and experience of using authentic materials and authentic assessment were employed from the beginning of the learning process in the classroom. A number of learning activities were also promoted to encourage authentic materials and authentic assessment in teacher education. The finding of this study is to prepare pre-service teachers in implementing authentic materials and authentic assessment in EFL classroom as well as their responses.

\section{METHODS}

The method of this study was action research. It was conducted to the fourth semester student of English Education Program at a university in Bogor. The class involved eleven students of pre-service teachers. The writers accompanied two cycles of learning process and adapted the spiral model of Kemmis et al.,(2014) involving the four steps: planning, acting, observing, and reflecting.

The data were obtained through four ways; documentation, observation, questionnaire, and interview. Documentation is started in the planning step. Observation is conducted in action step. Observation was administered to know the teaching-learning processes. The questionnaire is given after acting and observing steps completed as references in reflecting steps. The questionnaire was conducted to obtain data or information about the students' opinion toward the implementation of authentic materials and authentic assessment in the classroom. Interview was 
conducted to complete and support the data from observation, questionnaire, and documentation.

\section{RESULTS AND DISCUSSION Cycle I \\ Planning}

In the planning step, some necessary preparations were made, i.e. reading some literatures related to the application of authentic materials and assessment for EFL classroom. From the literatures, it turned out that students need to be exposed to authentic materials and authentic assessment. A lesson plan was then formed with the intention that teachers would use the authentic materials and authentic assessment in learning activity. The writers prepared teaching materials by collecting and selecting suitable materials. The authentic materials were taken from English Listening Lesson Library Online (ELLLO) which can be accessed freely at www.elllo.org. According to its official website, ELLLO provides lessons containing an MP3 file of an authentic conversation with a transcript of the conversation, vocabulary support, and a comprehension quiz. The writers chose listening materials with the duration of three minutes in average. The writers then prepared instrument for data collection.

\section{Acting}

In the acting step, the implementation was done in accordance with the prepared planning. Authentic materials taken from ELLLO were used. As the learning activity was conducted in the language laboratory, the materials were delivered through students' computer and they listened to the MP3 audio lesson through their headphones. Students could control the audio by using audio player. They can make pause, adjust the volume, or replay the audio as many as they wanted. A comprehension quiz of traditional assessment in form of multiple choices was given to the students. Traditional assessment was in the form of usual methods of assessment by using multiple choices. It was given to evaluate and measure students' listening comprehension and to determine their comprehension in acquiring information from the materials.

\section{Observing}

Observation was conducted during the learning process to analyze the implementation of learning activity in the previous cycle and to have direct observation to the students' behavior, especially in listening to the authentic materials. After observing the use of authentic materials followed by the assessment, it resulted that there were some important matters to take into account in the first cycle; (1) Students felt that it was too easy to understand the material content because they can read the transcript while listening to the materials; (2) Students thought that the duration of the materials from ELLLO was short with no more than five minutes; (3) Students would like to have materials with both audio and visual. (4) The quiz in the assessment was too easy for the students. It seemed they needed more challenging assessment to do.

\section{Reflecting}

In the reflecting step, the researchers examined the results of actions in the previous cycle. The reflecting step is the evaluation of the result of the acting obtained from observation. The results were used as references for other suitable and better alternative action to be implemented in the next cycle. Based on the result of the observation, the focus of the next plan would be to address the above problems by raising the content complication, using longer materials, having materials with both audio and visual and changing the type of assessment.

\section{Cycle II \\ Planning}

In the planning step of the second cycle, the writers had similar activity to the previous cycle. A lesson plan was created and developed to guide the class instruction. Teaching materials were collected and selected. After reading some related articles about authentic materials and authentic assessment, some instruments for data collection were prepared. For the classroom evaluation planning, it was done by reading some books related to the integration of authentic materials and authentic assessment in an EFL classroom from which the learning process can reach the optimum result. The writers collected and selected the authentic materials from TED (Technology, Entertainment, and Design) Talks. TED Talk consists of a videotaped presentation in the form of brief and influential talks in front of live audience. TED Talks are free to watch and can be accessed at www.ted.com. Finally, the researchers decided to use the following actions: (1) Authentic materials from TED Talks video with longer duration of more than five minutes would be used in learning activity. It was also chosen to accommodate audio-visual materials; (2) Authentic assessment would be given to students in the form of project-based assessment. It was selected to provide more complicated and challenging assessment. They were asked to find authentic materials of audio-visual from any sources and create questions and answers related to the content. The integration of both authentic materials and authentic assessment aims at promoting the students of preservice teachers to the materials and assessment.

\section{Acting}

In the acting step, the implementation was conducted according to the prepared planning. The selected materials of TED Talks video were delivered to students' computer and they were asked to watch the video. Similar to the activity in cycle I, students could control the video by using a video player. They can make pause, adjust the volume, or replay the video. In the learning process, question and answer session was given to discuss all the problems faced in understanding the materials. The discussion was about the content, vocabulary, accent, and language features of the authentic materials. In the end of teaching process, students were given a project in which they had to find authentic materials that can be used in listening activity from any sources and create questions and answers related to the chosen materials. The project given to the preservice-teacher students was one of authentic assessments 
because in their real life, as in-service teacher, teachers are required to search, select, and choose materials for their classroom and create assessments based on the materials.

\section{Observing}

The observation was addressed to the learning process and the result of it. In the learning process, the observation was used to know the level of learning achievement in using authentic materials and authentic assessment. This was supported by the observation result on the learning outcome. The result showed that the students could find and use a source of authentic materials and they were able to generate questions as a form of assessment based on the chosen materials. This data is supported by interview that was conducted after the completion of the course.

\section{Reflecting}

After observation, students were familiar to using authentic materials. Students felt that it was more challenging to comprehend the content because of the video's longer duration. Student also became more concentrated and focused watching and listening to the materials. The visual helped students grasp the content and engage with the materials for better comprehension. Students were also more comfortable and inspired with the authentic materials of TED talks. They also became more challenging in doing the project based-task given in the end of teaching process. From the observation conducted, it came to a conclusion that students were more enthusiastic, comfortable, inspired, and challenging in the teaching activity of cycle II than that in the cycle I.

Students also liked to have their learning assessed in authentic ways. Assigning such kind of task provides students a more meaningful way to show how they, as the pre-service teacher, will complete the task in the real world when they become in-service teachers. As a result, they will be able to engage their students about the use of authentic materials in the classroom to support learning objectives in Curriculum2013.

\section{The Integration of Authentic Materials}

The questionnaires were distributed to obtain data or information regarding the integration of authentic materials in the classroom. From the data gathered, it was found that students were not familiar with authentic materials at first. The data shows that most students had ever used authentic materials in the previous courses namely Academic Writing. However, the materials in the previous course were in the form of scientific article and were categorized as authentic visual materials, not listening-viewing materials. In addition, the use of the materials was limited as supplementary materials. This indicates that the students have little familiarity with authentic materials. Whereas, authentic materials need to be more introduced and exposed to pre-service teachers. Oguz \& Bahar (2008) in line with Sari (2016) assumed that it is crucial for authentic learning environments organized in pre-service teacher training and prospective teachers to be educated in authentic environments which have a connection to the real world and in which they have a chance to experience using authentic materials. The necessity to equip them with such qualifications makes it compulsory to increase the quality of education presented to the students. María et al., (2018) suggest that teachers may use authentic materials for the learners to listen for the gist of the information presented and they add that by using authentic materials teachers will have the opportunity to encourage students to read for pleasure especially certain topics of their interest.

The other data showed that authentic materials were challenging. This is in line with the findings of Astika \& Kurniawan (2020) in their study of TED Talks use as a materials resource that the students encountered challenges in understanding the speaker because of the rate of speech, pronunciation, and vocabulary. Students assumed that the speaker talked too fast that they could not catch the information well and needed to replay the talk many times.

"The way the speaker speaks is too fast for me that I miss the information." (Student 6)

Students perceived that the speaker's pronunciation was unusual and unique. This is because TED talk has speakers from around the world with different accent. In other words, they lacked the ability to understand varieties of English accents by speakers from different nationalities. Another difficulty is the intonation of the speaker with different accent. Most students mentioned that they could not understand the talk because of the different accent, the speaker does not use American or British accent.

"I found strange and different ways of pronunciation as well as the stress when the speaker speaks" (Student 1)

Insufficient stock of vocabulary also becomes the students' problem. Many of them experienced difficulty with the vocabulary. Compared to ELLLO, the materials in TED Talks were perceived as the most difficult.

"I cannot understand part of the talk because I don't know the meaning of some words." (Student 4)

"The vocabularies of TED Talks video are difficult." (Student 11)

In regard to motivation, students were motivated with authentic materials in learning activity. They assumed that the speakers in both TED Talks and ELLLO talk expressively. However, compared to ELLLO, TED Talks was considered more motivated. Students said that TED Talks consists of not only the audio but also visual which were more engaging and meaningful lesson. The speech content was also assumed to share inspiring ideas.

"I always excited to discuss the materials of TED Talks in listening class." (Student 7)

"The materials from ELLLO and TED Talks provide inspiring and motivational messages with lots of language variation." (Student 8)

Peacock (1997) has shown that authentic materials promote motivation for learning. The materials give authentic cultural information, expose students to real language use, and relate more closely to students' needs (Astika \& Kurniawan, 2020). Furthermore, Citra Dewi 
(2018) assumed that the learners should get the opportunities to practice by adapting or listening the real language as authentic texts and materials in their classroom situations to master the foreign language. Bacon \& Finnemann (1990) and Citra Dewi (2018) suggest that authentic aural texts as the source of learning can be used to increase students' motivation and self-satisfaction. It is advantageous to use authentic materials in teaching foreign language to increase students' motivation. Kiliçkaya (2004) assumes that the use of authentic texts is a technique which can be used in language learning to increase students' motivation because the students feel that they are learning the real language. Sari (2016)finds that the learners were mostly motivated by using authentic materials because they are exciting to be discussed in the class, interesting to learn and appealing to the learners.

Other results showed that both ELLLO and TED Talks gave significant contribution in enhancing listening ability. Most students acknowledged the materials enhanced their knowledge about pronunciation and the varieties of accents. The transcript or subtitles give students information about what they are listening and how to pronounce it.

"From TED Talks and ELLLO, I can learn pronunciation and the varieties of accents, not only American and British accent." (Student 1)

"I can learn how to pronounce the words in the subtitle by paying attention to the speaker's pronunciation." (Student 6)

María et al. (2018) noticed that the specific characteristics of the video such as movement, sound, and color, permit students to get engaged and understand the topics presented easily; thus, students improve significantly their listening skill. Students memorize vocabulary easily and fast. This is also confirmed by Astika \& Kurniawan (2020) that the online sources of TED talks should have provided support and had beneficial effects on student's pronunciation development. The use of authentic materials should get more interest in teaching listening, and learners should be exposed to real-life input. Based on the student comments, pedagogical input was created after using the authentic materials.

\section{The Integration of Authentic Assessment}

Based on the collected data, the students said that the assessments which were commonly used in the previous courses were traditional assessment as it is depicted in the interview result given by the student below. Traditional assessments in the form of essays and multiple choices were given to the students. The assessment was given to students to evaluate their comprehension and acquisition of the content.

"We were given evaluation test in the form of essays and multiple choices." (Student 9)

It is admitted that authentic assessment has some challenges in its implementation. Fox (2017) stated that challenges may be encountered in the form of student resistance, working with large groups and resource and time constraints. Hart et al. (2011) also confirm that authentic tasks may require or be perceived to demand a greater investment of time and resources than more traditional assessments. In line with the assumption above, Aliningsih \& Sofwan (2015) and Riyani (2019) also find that the teachers' main problem in applying the authentic assessment is that they have large number of students, exhausting and time consuming activities, and complicated administration. Therefore, it is challenging for teachers of English to implement authentic assessment in their classroom. As written above, most teachers assume that authentic assessment is a hard activity to implement in class.

However, students assumed that authentic assessment was more meaningful than traditional one. They assumed that the tasks in authentic assessment have real-life relevance and genuine. It allows them to take control of their own learning rather than simply recalling facts. Authentic assessment requires students to create a product to show what they know and can do.

"Having authentic assessment is interesting because I can learn to create a real project in my future career as teacher." (Student 5)

It is essential for teacher to give more meaningful tasks to make learners get into rich content. Rusmawaty et al (2018) believe that authentic materials are able to stimulate students' motivation to learn in which they can support students' opportunities to intermingle with real uses of language rather than artificial materials which are made for learning purposes only. Authentic assessments allow students to find a way to demonstrate their knowledge that best suits them. Authentic assessment engages students in processes and evaluations that are meaningful to them, both now and in the future (Fox, 2017). Students are influenced to move from being consumers of knowledge to creators of knowledge (Swaffield, 2011).

Based on the level of difficulty of traditional assessment compared to authentic assessment, most students assumed that authentic assessment was more difficult than traditional assessment. In regard to the project-based task given in cycle II, students assumed that it was not easy to make authentic assessment especially in the process for creating an authentic assessment i.e., in identifying the standards, selecting an authentic task, identifying the criteria for the task.

"I have difficulty in classifying the materials based on the need." (Student 4)

Some research confirmed that to assess students is challenging, complex and crucial. Umam\& Indah (2020) argue that teachers find it difficult to implement the approach in the classroom because they believed that one of the problems in implementing authentic assessment is the rigid steps.

\section{CONCLUSION}

Curriculum 2013 requires teachers to implement authentic materials and authentic assessment. However, this research proves that many pre-service teachers are not 
accustomed to the authentic materials and authentic assessment. It is recommended that pre-service teachers are introduced in their learning process with a wide variety of authentic materials and authentic assessment. This can be done by integrating authentic materials and authentic assessment in the content-based courses and skill-based courses in pre-service English teachers' classroom. They should also be offered updated, attractive, interesting, motivating, and meaningful authentic materials to accommodate the demands of Curriculum 2013. Exposure to authentic materials and authentic assessment to pre-service teachers in teacher education program leads to their competence in using the approach in their future professional as a teacher.

\section{ACKNOWLEDGEMENTS}

The present writers would like to express our deep appreciation to Amalul Umam, MA.,TESL and Movi Riana Rahmawanti, SS. MA for their careful reading and helpful comments. Our thanks are also extended to the editors and reviewers for their thoughtful comments that helped us improve the quality of this research.

\section{REFERENCES}

Aliningsih, F., \& Sofwan, A. (2015). English teachers' perceptions and practices of authentic assessment. LANGUAGE CIRCLE: Journal of Language and Literature, 10(1), 19-27. https://doi.org/10.15294/lc.v10i1.4154

Arianie, M. (2017). Authentic material and interactive activities in efl classroom. English Franca: Academic Journal of English Language and Education. 1(2), 115 134. https://doi.org/10.29240/ef.v1i2.289

Astika, G., \& Kurniawan, A. (2020). The challenges of using TED Talks as authentic resources of academic listening for EFL university students. Indonesian Journal of Applied $\quad$ Linguistics. 9(3), 589-598. https://doi.org/10.17509/ijal.v9i3.23209

Bacon, S. M., \&Finnemann, M. D. (1990). A study of the attitudes, motives, and strategies of university foreign language students and their disposition to authentic oral and written input. Modern Language Journal, 74(4), 459-473. https://doi.org/10.2307/328520

Citra Dewi, R. (2018). Utilizing authentic materials on students' listening comprehension: does it have any influence? Advances in Language and Literary Studies. 9(1), 70-74. https://doi.org/10.7575/aiac.alls.v.9n.1p.

Fox, James, et. al. (2017). "Keeping it Real": A review of the benefits, challenges and steps towards implementing authentic assessment. AISHE-J - The All Ireland Journal of Teaching and Learning in Higher Education, 9(3),3231-

3244.URL:http://ojs.aishe.org/index.php/aishej/article/vi ew/ 280
Hart, C., Hammer, S., Collins, P., \& Chardon, T. (2011). The real deal: using authentic assessment to promote student engagement in the first and second years of a regional law program. Legal Educ. Rev., 21 (1), 97122 .

Kemmis, S., McTaggart, R., Nixon, R., Kemmis, S., McTaggart, R., \& Nixon, R. (2014). A new view of participation: participation in public spheres. InThe Action Research Planner. https://doi.org/10.1007/978-981-4560-67-2_2

Kiliçkaya, F. (2004). Authentic materials and cultural content in efl classrooms. The Internet TESL Journal,10(7).

Kinay, I. (2018). Investigation of prospective teachers' beliefs towards authentic assessment. World Journal of Education. 8(1), 75-85. https://doi.org/10.5430/wje.v8n1p75

Lee, W. Y. chun. (1995). Authenticity revisited: text authenticity and learner authenticity. ELT Journal, 49(4), 323-328, https://doi.org/10.1093/elt/49.4.323

María A, M. H., Junior A, V. C., \& Astrid, R. V. (2018). TED Talks as an ICT Tool to Promote Communicative Skills in EFL Students. English Language Teaching. 11(2), 106-115. https://doi.org/10.5539/elt.v11n12p106

Montgomery, K. (2002). Authentic Tasks and Rubrics: Going Beyond Traditional Assessments in College Teaching. College Teaching. 50(1), 34-40. https://doi.org/10.1080/87567550209595870

Mueller, J. (2017). Authentic Assessment Toolbox. 2017.http://jfmueller.faculty.noctrl.edu/toolbox/

Nurkamto, J. (2016). Teachers' Creativity in Transforming the Mandated Curriculum into a Linguistically and Culturally. Proceedings of the Fourth International Seminar OnEnglish Language and Teaching (ISELT-4), May, 11-12.

Oguz, A., \& Bahar, H. O. (2008). The Importance of Using Authentic Materials in Prospective Foreign Language Teacher Training. Pakistan Journal of Social Sciences.3(4), 328-336.

Olfos, R., \& Zulantay, H. (2007). Reliability and validity of authentic assessment in a web based course. Educational Technology and Society, 10 (4), 156173.

Peacock, M. (1997). The effect of authentic materials on the motivation of EFL learners. ELT Journal.51 (2), 144-156. https://doi.org/10.1093/elt/51.2.144

Permendikbud No. 104 year 2014. (2014). Nomor 104 Tahun 2014 Tentang Penilaian hasil Belajar Oleh Pendidik Pada Pendidikan Dasar dan Pendidikan Menengah. Pedoman Evaluasi Kurikulum.

Permendikbud No. 81A. (2013). Permendikbud Nomor 81A Tahun 2013 Tentang Implementasi Kurikulum. 


\section{Permendikbud.}

Richards, J. C. (2001). Curriculum Development in Language Teaching. In Curriculum Development in Language Teaching.(Series Ed). Cambridge University Press. https://doi.org/10.1017/cbo9780511667220

Riyani, T. S. and C. (2019). Authentic Assessment in Elt: Hopes, Challenges, and Practices. Jurnal Ilmiah Kependidikan.9 (2), 112-120.

Rukmini, D., \& Saputri, L. A. D. E. (2017). The authentic assessment to measure students' English productive skills based on 2013 Curriculum. Indonesian Journal of Applied $\quad$ Linguistics. $\quad 7(2), \quad 263-273$. https://doi.org/10.17509/ijal.v7i2.8128

Rusmawaty, D., Atmowardoyo, H., Hamra, A., \& Noni, N. (2018). Teachers' Beliefs of Authentic Materials for Teaching Reading in Indonesian EFL Classrooms. Journal of Language Teaching and Research.9 (3), 608613. https://doi.org/10.17507/jltr.0903.21

Sari, D. F. (2016). Authentic Materials for Learning

Conflict of Interest Statement: The authors declare that the research was conducted in the absence of any commercial or financial relationships that could be construed as a potential conflict of interest.
English: A Study on EFL Students in Aceh. Studies in English Language and Education.3(2), 147-157. https://doi.org/10.24815/siele.v3i2.4962

Swaffield, S. (2011). Getting to the heart of authentic Assessment for Learning. Assessment in Education: Principles, Policy and Practice.18 (4): 433-449. https://doi.org/10.1080/0969594X.2011.582838

Trisanti, N. (2014). English teacher's perspective on authentic assessment implementation of curriculum 2013. The 61st TEFLIN Intenational Conference, $1173-1175$.

Umam, A., \& Indah, Y. A. (2020). Exploring In-Service TEYL Teachers' Assessment Literacy: Implication For Continuing Professional Development. JEES (Journal of English Educators Society). 5(1), 47-51. https://doi.org/10.21070/jees.v5i1.364

Varela, E., O’Malley, J. M., \& Pierce, L. V. (1997). Authentic Assessment for English Language Learners: Practical Approaches for Teachers. Longman. New York.

Copyright (C) 2021 Alan Jaelani \& Amalul Umam. This is an open-access article distributed under the terms of the Creative Commons Attribution License (CC BY). The use, distribution or reproduction in other forums is permitted, provided the original author(s) and the copyright owner(s) are credited and that the original publication in this journal is cited, in accordance with accepted academicpractice. Nouse, distribution or reproduction isp ermitted which does not comply with these terms. 